Abstracta Iranica Abstracta Iranica

Revue bibliographique pour le domaine irano-aryen

Volume 30 | 2010

Comptes rendus des publications de 2007

« Pouvoir et noblesse dans l'empire moghol. Perspectives du règne de Jahāngīr (1605-1627) ». Annales. Histoire, Sciences Sociales, 6, 2007, pp. 1287-1312.

Alexandre Papas

\title{
OpenEdition
}

Journals

Édition électronique

URL : http://journals.openedition.org/abstractairanica/37814

DOI : 10.4000/abstractairanica.37814

ISSN : 1961-960X

Éditeur :

CNRS (UMR 7528 Mondes iraniens et indiens), Éditions de l'IFRI

Édition imprimée

Date de publication : 8 avril 2010

ISSN : 0240-8910

Référence électronique

Alexandre Papas, « «Pouvoir et noblesse dans l'empire moghol. Perspectives du règne de Jahāngīr (1605-1627) ». Annales. Histoire, Sciences Sociales, 6, 2007, pp. 1287-1312. », Abstracta Iranica [En ligne], Volume 30 | 2010, document 159, mis en ligne le 08 avril 2010, consulté le 27 septembre 2020. URL: http://journals.openedition.org/abstractairanica/37814; DOI : https://doi.org/10.4000/ abstractairanica.37814

Ce document a été généré automatiquement le 27 septembre 2020.

Tous droits réservés 


\section{« Pouvoir et noblesse dans l'empire moghol. Perspectives du règne de Jahāngīr (1605-1627) ». Annales. Histoire, Sciences Sociales, 6, 2007, pp. 1287-1312.}

\section{Alexandre Papas}

Axée sur le règne d'Akbar et fondée sur les chroniques officielles, l'historiographie a pris l'habitude de représenter l'empire moghol comme un État fortement centralisé, parvenu à une maitrise accomplie de sa noblesse régionale. En portant le regard sur le règne du successeur et fils d'Akbar, Jahāngīr, et en exploitant des sources alternatives issues de la noblesse elle-même, l'A. décrit une situation historique tout autre. Les portraits de deux amìr éminents, l'iranien 'Abd al-Rahīm (1556-1627) et l'afghan Hān Jahān (1580-1631), montrent que l'élite administrative jouissait d'un pouvoir territorial propre. Aux mains d'individus ou de familles nobiliaires, dont le pouvoir s'affermissait au cours du temps, les provinces périphériques échappaient au contrôle impérial au point de reproduire une souveraineté de cour à l'échelle des régions, or cela, bien avant Jahāngīr, et bien après, au XVIII ${ }^{e}$ s., lorsque des Etats régionaux seront créés par des amir.

INDEX

Thèmes : 4.2.3. Inde musulmane 
AUTEURS

ALEXANDRE PAPAS

CNRS - Paris 